\title{
THE PROBLEM OF PERSONAL INCOME TAX AVOIDANCE
}

\author{
HARRY J. RUDICE*
}

\section{INTRODUCTORY}

During its current term, the Supreme Court has rendered three decisionsGriffiths v. Helvering, ${ }^{1}$ Higgins v. Smith, ${ }^{2}$ and Helvering v. Clifford ${ }^{3}$-which focus the tax spotlight on personal income tax avoidance. In the light of these decisions, the intending tax avoider may at first despairingly conclude that avoidance is a dead letter; that Congress need only impose a tax and the Court will stand guardian to see that it is not avoided; that if Congress has the power to tax a transaction it is as good as taxed." But taxpayers are human. Hope springs eternal in their breasts; and, if past experience is a guide, the Court's action will only dampen their efforts to escape tax; it will not extinguish them.

Taxes and tax avoidance were probably born twins and are likely to conitinue their joint existence until the millennium of a taxless world. Avoidance is Hydraheaded and, as the tax gatherers, aided by the Supreme Court, discover and cut off one escape contrivance, the taxpayer rears up another. Even today, with all three branches of the government-legislative, administrative and judicial-hot on the trail of the tax avoider, the mails are flooded with circuiars advertising books and services telling how to save income taxes. ${ }^{5}$ The size of the market for this material

- B.C.S., I921, New York University; LL.B., r927, Brooklyn Law School. Member of the New York Bar. Lecturer in Law, New York University Law School. Author, Section I0z and Personal Holding Company Provisions of the Internal Revenue Code (1939) 49 YALE L. J. I7I.

308 U. S. 355 (1939).

308 U. S. 473 (1940).

-60 Sup. Ct. 554 (1940). A companion case, Helvering v. Wood, 6o Sup. Ct. 551 (1940), was won by the taxpayer, but apparently only because the government expressly waived below reliance on the ground which would have given it victory.

"The broad sweep of this language [\$22(a)] indicates the purpose of Congress to use the full measure of its taxing power within those definable categories." Helvering v. Clifford, supra note 3 , at 556.

${ }^{5}$ It should be evident from the following list of methods of reducing personal income tax which are currently in vogue that, although avoidance may be moribund, its extinction is remote enough for the comfort of tax practitioners. This list is by no means all inclusive; nor is there any assurance that the methods listed will survive if attacked:

(1) A holder of preferred stock called for redemption may, by selling before the redemption date, take advantage of the limited capital gains rate, if he has held the stock more than 18 months. Otherwise, the gain on redemption would be from a partial liquidation and subject to ordinary tax rates as 2 short-term gain.

(2) A taxpayer selling a portion of his holdings of a security, acquired at different times and costs, may, by delivering particular certificates (or appropriately instructing his broker in the case of a margin account) manipulate his gain or loss advantageously. 
suggests that perhaps the government has misconceived the average individual's attitude toward circumvention of tax; and that the citizenry, by and large, does not share the sanctimonious abhorrence of tax avoidance expressed by Congressional committees, Treasury officials and members of the judiciary. Judge Green has observed that "Americans, as a nation, are always inclined to insist on all of the technicalities of the law if anything can possibly be gained thereby ${ }^{6} \ldots$ and when it comes to tax avoidance . . . the American under the guidance of skilful lawyers is a past master." Deplorable though it be, it is probably true that the average individual taxpayer, large or small, would prefer to pay higher tax rates ${ }^{8}$ and preserve his until recently vested right to escape from tax if the law literally permits such escape. ${ }^{\circ}$

No attempt will be made herein to catalogue all the ingenious and pseudoingenious methods employed by taxpayers and their counsel-someone has coined the word "taxperts" to describe them-to elude the clutches of a hungry and ubiquitous Treasury. This article will be confined, in the main, to a discussion in chronological order of certain Supreme Court cases touching on the subject of personal income tax avoidance; and to an endeavor, from these cases, to discover and articulate the judicial attitude toward the subject.

\section{Definition of Income Tax Avoidance}

Before proceeding to a necessarily brief general history of income tax avoidance, it would be well to stake out a definition of the term. This definition, for present

(3) A corporation by declaring a non-taxable stock dividend, instead of a cash dividend, cnables the stockholder to obtain cash by sale of the stock dividend with a minimum of tax.

(4) The sale of stock by one member of the family to register a loss, and a contemporaneous purchase of other shares of the same stock by another member of the family.

(5) A taxpayer may, by making a technical short sale of stock, i.e., a sale "against the box," postpone tax on the profit or defer the loss until he chooses to deliver the stock against the short sale.

(6) Current income of estates in administration can often be made taxable either to the fiduciary or to the beneficiary, whichever is most advantageots. Similarly, property about to be sold can be sold by either the fiduciary or the legatees.

(7) Irrevocable transfers of income-producing property to members of the family (or others) in lower tax brackets, whether by outright assignment or by the creation of irrevocable trusts, including trusts of the type suceessfully-thus far-employed in Knapp v. Hocy, 104 F. (2d) 99 (C. C. A. 2d, 1939), and Commissioner v. Dean, 102 F. (2d) 699 (C. C. A. 10th, 1939).

(8) A donor may make a charitable contribution not in cash but in property which has enhanced in value, deducting the value of the property; the enhancement in value eseapes tax.

(9) Investment in tax-exempt securities.

(10) The use of pension trusts, thereby shifting income from years of high salaries to those years of retirement when the income will fall into lower brackets.

(II) The use of elections granted by law, such as the privilege of husband and wife to file joint or separate returns; adopting a fiscal year: using percentage depletion which, for no compelling reason, permits the taxpayer to recoup tax-free more than the cost of his property; reporting profit on an instalment sale over the period of collection.

- Green, The Theory and Practice of Modern Taxation (2d ed. 1938) 132.

Td. at 147 .

- Mr. Paul has pointed out that revenue loss from tax avoidance is only superficial. "Governments must live, and the avoided tax is passed to and lightly spread among 2 tax-paying public, which might, if it were asked, accept the additional burden in exchange for greater certainty." PAut, Studies IN Federal TAXation (1937) 156.

'Id. at 82-88, especially rotes 283-286. The lower courts have, as a rule, been more tolerant toward tax avoidance than the centralized Supreme Court. 
purposes, need not take into account the subtleties involved in distinguishing between tax avoidance and tax evasion. ${ }^{10}$ For our purposes, it will be assumed that income tax avoidance covers every conscious attempt, successful or unsuccessful, to prevent or reduce income tax liability by taking advantage of some provision or lack of provision in the law. This definition, which excludes fraud or concealment, presupposes the existence of alternatives, one of which will result in lesser tax than the other, or at least so it is hoped. The law openly countenances certain types of avoidance, e.g., investment in tax exempt securities; the mere investment makes exemption automatic. But the controversy with respect to such avoidance is one of policy, rather than of law; and, while we are concerned with it, there is not much of law to be discussed in connection with it.

\section{General Histort}

It is amazing that no case which directly touched the subject of income tax avoidance reached the Supreme Court until 1929, ${ }^{11}$ more than fifteen years after the enactment of the first income tax law of the modern era. Indeed, it was not until I935 that a case reached the Court in which the taxpayer openly admitted that her motive for shaping the transaction in issue was income tax avoidance. 12 The causes for this delay are elusive. Lack of avoidance certainly was not one of them. Possible reasons which suggest themselves are:

(1) The curve of tax avoidance will probably tend to follow tax rates, and tax rates were low in the early income tax years. This will undoubtedly.be true of such types of avoidance as investment in tax exempt securities, or the use of optional methods permitted by the law; but it is not a particularly convincing explanation with respect to other types of avoidance. Avoidance was plentiful even during the low surtax period of $1928-1931^{13}$ A contributing factor might be a tendency on the part of the Treasury to grow apathetic toward tax avoidance when tax rates are low, and the Treasury's pockets are bulging. ${ }^{14}$

(2) The provisions of the early laws were vague and general-as contrasted with

${ }^{10}$ Mr. Paul discusses the distinction thoroughly. Patr, op. Cit. supra note 8, at 12-19. See also Altman, Recent Developments in Income Tax Avoidance (1934) 29 lux. L. REv. 154, 157; and GreEs, op. cit. supre note 6, at 134. Some judges have used the terms indiscriminately and the dictionaries in Eact treat the terms as synonyms. Nlthough many judges and writers to to preserve the distinction, it is becoming increasingly blurred. For those who prefer to continue the logomachy, the distinction may be cynically but practically expressed in the remerk that avoidance is merely successful evasion and evasion is unsuccessful avoidance; "aroidance being what works, and evasion being what fails." Pav, op. cit. sapre note $8,2 t$ 14.

12 The case was Taft v. Bowers, 278 U. S. 470 (1929), discussed infra, p. 248. But sce note 38 infra.

12 Gregory v. Helvering, 293 U. S. 465 (1935), discussed infre, p. 254 . In some carlier cases the avoidance motive mas implicit.

${ }^{12}$ See Benad, Axenuca in Mrd-Passage (1939) 186-187. One faction of the Ways and Means Committer, in the report on the 1924 Act, naively recommended that the rates be reduced 402 point where the temptation to avoid, if not entirel; climinated, will, 2 least, be less compelling. . ." H. R. REP. Na. 179, 68th Cong., ist Sess. (1924) 38 .

26 However, in 1924, despite an estimated Treasury surplus of more than $\$ 300,000,000$, and a geners reduction not only of future but of past tax rates, 2 substantial number of provisions to prevent aroidance were enacted. 
the highly particularized statute in force today. ${ }^{15}$ This vagueness probably acted as a brake on avoidance since general terms give the Treasury Department and the courts ample room for constructions which will prevent or discourage circumvention. ${ }^{30}$ Certainly particularization breeds avoidance.

(3) The Treasury Department in the early years was not the vast organization that exists today. The number ${ }^{17}$ and quality of its personnel were not up to present standards. It was timid and beset-as was Congress itself prior to 1932-by fear of the bogey of unconstitutionality. Today Congress and the Treasury have fesv qualms. about constitutionality, and attack on that ground is almost hopeless. The current Treasury Department-timidity is not one of its faults-contends that the definition of income in the Income Tax Law is co-extensive with the power of Congress to $\operatorname{tax}^{18}$ and the Supreme Court has virtually upheld this position. ${ }^{10}$

(4) Some of the early inertia towards avoidance probably resulted from a too wholesome respect for a case decided by the Supreme Court in $1873:$ Isham v. United States. ${ }^{20}$ That case involved a prosecution for failure to affix a stamp to an instrument which the government maintained was taxable under the statute of 1864 . The government contended that even though the form of the instrument was such as to exclude it from the literal application of the stature, it was in fact an instrument of the type made subject to tax; and that the transaction was a device to avoid payment of the duty and its operacion was a fraud on the law. The Court rejected this argument. It held that the form of the instrument, rather than its operation, controlled, and that a device to avoid the payment of tax is subject to no legal censure if carried out by the means of legal forms. ${ }^{2 x}$

Today, of course, this is an outmoded philosophy, as the cases discussed below will show; although the Court paid lip service to it as late as the Gregory case in $1935 .{ }^{22}$ But, while it lasted, many a tax avoider turned to it as a refuge; and the lower courts and the Board of Tax Appeals, in many cases, justified his faith.

As the years rolled on and the Treasury and Congress awakened to the realization that avoidance was rife, the process of statutory amendment was adopted as a means of checking it; and there were enacted particular provisions to prevent specific types

25 The Revenue Act of 1913 consisted of about two dozen pages; the current income tax provisions of the Code comprise. more than 100 pages and at least half of the substantive provisions were canced to prevent zvoidance.

10 Note that the general and elastic language of $\$ 22(2)$ rather than the precise provisions of $\$ 5 i 66$ and 167 enabled the Treasury to tax the grantor in Helvering v. Clifford, supra note 3, discussed infra p. 258.

${ }^{27}$ The personnel of the Burezu of Internal Revenue in 1913 was less than 4,000; by 1938 it had groxn to 25,000 .

13 Sce, e.g., the government's brief, p. 5 , in Helvering v. Bruun, 60 Sup. Ce. 631 (1940).

20 Helvering v. Clifiond, supra note 3.

21 a. . To illustrate. The Stamp Act of 1862 imposed a duty of two cents upon a bank chick, when drawn for an amount not less than twenty dollars. A careful individual, having the amount of twenty dollars to pay; pays the same by handing to his creditor two checks of ten dollars each. He thus draws checks in payment of his debt to the amount of twenty dollars, and yet pays no stamp duty. This practice and this system he pursues habitually and persistently. While his operations deprive the government of the duties it might reasonably expect to receive, it is not perceived that the practice is open to the charge of fraud. He resorts to deviees to avoid the payment of duties, but they are not illegal. He has the legal right to split up his evidences of payment, and thus to avoid the tax. The device we are considering is of the - same nature" Id. at 506.

"Gregory :. Helveriog, supre note 12. 
of avoidance. But, as has already been observed, particularization in a statute leaves less room for the play of judicial interpretation; and hence, while a particular device is eliminated, avoidance in general is not decreased. In other words, particularization reaches its immediate objective but gets no closer to the ultimate goal. It wins the battles but loses the wars. So while the legislators passed amendments right and left, they discovered that when they closed the dike in one place, they often used an implement which opened up a hole right next to it. Congress was fighting a losing battle until the Supreme Court came to its aid in the Gregory case. Taxpayers were becoming bolder and bolder, and, relying, with a confidence built up by earlier cases, on the doctrine that the law meant what it said, were pursuing every scheme that complied with the law as it read. Generally speaking, the lower courts justified this confidence, but with the Gregory decision the avoidance balloon was considerably deflated. Taxpayers discovered that no longer did safety lie in the literal meaning of the statute. ${ }^{28}$

It cannot be said that the debacle came altogether without warning. The Court in earlier cases, notably Woolford Realty Co. v. Rose, ${ }^{24}$ and Dupont v. Commissioner $^{25}$ had displayed rather clearly its hostility to avoidance. Even after the Gregory decision, many taxpayers buried their heads in the sand and continued to rely on the mere words of the law; and, while successful in some cases, their average is a poor one. Of course, many taxpayers who attempt tax avoidance are no worse off if their attempt fails, save for the expense of contesting the issuc. Often, however, taxpayers come to more serious grief. This may be especially true of those who attempt to keep their cake and eat it too: they are likely to awaken with a case of indigestion; as where an individual has created a trust for the benefit of another with the idea of avoiding tax and finds himself not merely taxed on the income, but subjected to gift tax as well. ${ }^{26}$

In Burnet v. Wells, ${ }^{27}$ Mr. Justice Cardozo remarked: "One can read in the revisions of the Revenue Act the record of the Government's endeavor to keep pace with the fertility of invention whereby taxpayers had continued to keep the larger benefits of ownership and be relieved of the attendant burdens." The compass of this paper does not permit an enumeration or historical treatment of these revisions, ${ }^{28}$ although some of them are adverted to in connection with the Supreme Court cases discussed herein. That they succeeded to a large degree cannot be doubted; but that they have not completely stopped avoidance is equally certain. Their study reveals that

"They were later to discover that it is even risky to rely on the decisions of the Supreme Court itself. Note O'Malley v. Woodrough, 307 U. S. 277 (1939), Graves v. O'Keefe, 306 U. S. 466 (1939), and Helvering v. Mountain Producers Corp., 303 U. S. 376 (1938), overruling respectively Miles v. Graham, 268 U. S. 501 (1925), Collector v. Day, II Wall. II3 (U. S. r87r), and Burnet v. Coronado Oil \& Gas Co., 285 U. S. 393 (1932). Note also Helvering v. Hallock, 6o Sup. Ct. 444 (1940) (an estate tax case) overruling Becker v. St. Louis Union Trust Co., 296 U. S. 48 (1935).

14 286 U. S. 319 (1932).

20. For another example, see Royal Marcher, 32 B. T. A. 76 (1935).

${ }^{17} 289$ U. S. $670,675-676$.

20 The major offensives of Congress against income tax avoidance took place in 1924, 1934, and 1937 . This was practically the sole raison d'etere of the 1937 Act. See Paul, The Background of the Reventue Act of 1937.(1937) 5 U. OF Cm. L. REv. 4I. 
most of them are directed against two broad categories of avoidance: ( $\mathrm{I}$ ) attempts to siphon off income from high to lower surtax brackets by means of trusts, controlled corporations, and intra-family arrangements; (2) attempts to use the same means to obtain artificial deductions or to shift losses to where they will do the most good taxwise.

The Supreme Court's major contributions to the law of personal income tax avoidance ${ }^{28}$ were its decisions in Taft v. Bowers; ${ }^{30}$ Lucas v. Earl; ${ }^{31}$ Corliss v. Bowers; ${ }^{32}$ Poe v. Seaborn; $;^{33}$ Burnett v. Wells; $;^{34}$ Gregory v. Helvering; ${ }^{35}$ National Grocery Co. $v$. Helvering; ${ }^{36}$ and the three cases referred to at the beginning of this article. ${ }^{37}$ These cases will now be considered.

\section{The Judicial Landmarks}

Congress would never have advanced far in its battle to obstruct income tax avoidance if the Supreme Court had not stood by it. That the Court has been a faithful ally is evident from the fact that, except for Eisner $v$. Macomber, personal income tax avoidance provision has ever been declared unconstitutional."

(a) Taft $v$. Bowers (1929)..$^{10}$ Basis for property acquired by gift: Prior to 1921, the Revenue Act contained no specific provision with respect to the basis (for computing gain or loss on sale) of property acquired by gift. The statute did contain 2 specific provision excluding from gross income the value of property acquired by gift. The Treasury Department ruled that the proper basis for property so acquired was its fai $i$ market value at the time of acquisition. It could hardly have done otherwise in the face of the law as it then stood. As a consequence, the door to the avoidance of tax on capital gains was opened wide. Suppose a taxpayer had an asset worth $\$ 100,000$ which cost him $\$ 10,000$. If he sold it for the former amount, he would incur liability to tax on a gain of $\$ 90,000$. But if he gave it to his wife or someone else near to him, the donee could sell it without paying any tax: the gain of $\$ 90,000$ escaped tax completely. Congress slammed the door shut in the 1921 Act when it provided that the basis of property acquired by gift $^{41}$ should be the same as it would be in the hands of the donor. The validity of the provision was immediately challenged in the Taft case. The Supreme Court unanimously sustained the Act, giving as one of its reasons the fact that the provision was necessary and appropriate to prevent avoidance. Mr. Jüstice McReynolds, who wrote the opinion, also advanced the argument that the government was a sort of partner in the gain and could not

"See PaUr, op. cit. supre note 8, at 9-12 for 2 diseussion of the phrase "law of income tax avoidance."

${ }^{30} 278$ U. S. 470 (1929).

82, 28 1 U. S. 376 (1930).

3289 U. S. 670 (1933).

304 U. S. 282 (1938).

32 28I U. S. III (1930).

18282 U. S. 10\% (1930).

2893 U. S. 465 (1935).

"r. Supra notes 1,2 , and 3 .

28252 U. S. 189 (1920), tha famous 5 to 4 decision holding that the income tax on a stock dividend of common on common was unconstitutional. Perhaps this should not be classified as an income tax avoidance case.

"2) Cf. Heiner v. Donnan, 285 U. S. 312 (1932) (etate tax); Hocper v. Wisconsin, 284 U. S. 206 (1931) (state income tax); Schlesinger v. Wisconsin, 270 U. S. 230 (1926) (state inheritance tax).

${ }^{10} 278$ U. S. 470 (1929).

41 The amendment affected and still affects only gifts made after Dec. 3r, 1920. 
be deprived of its share of the gain. This reasoning foreshadows the validity of a provision, advocated by some, taxing a decedent's estate on enhancement in value of property occurring during his lifetime.

After the 192I amendment, it took the legislators thirteen years to discover that in successfully blocking this loophole they had unwittingly opened another. The law, beginning with I92I, required that the basis to the donee for computing gain or loss should be the same as it would be.in the hands of the donor. This permitted the transfer of losses from one person with a small income to another with a large income. For example, suppose a taxpayer had property costing \$100,000 which was worth only $\$ 5,000$. Assume further he had no income against which to offset the loss on a sale of this property. In such a case, he could give the property to a relative or close friend with a large income. The latter would sell the property, and, using as his basis the cost to the donor, could offset the loss against his income. The 1934 Act effectively stopped this practice by providing that, for determining loss, the basis to the donee should be either the donor's basis or value at the time of the gift; whichever is lower.

(b) Lucas v. Earl (1930).42 Assignments of income: The contact of Lucas $v$. Earl with the law of tax avoidance was fortuitous. It was not, strictly speaking, a tax avoidance case at all, because the taxpayer, Earl, had made no attempt to avoid federal income taxes. In rgor, long before the Sixteenth Amendment, he had made an agreement with his wife whereby whatever property either might thereafter acquire, by earnings or otherwise, should be owned by them jointly. Because of this contract, Earl contended that he was taxable on only half his salary and attorney's fees, and that his wife was taxable on the other half. However, the Supreme Court rejected Earl's argument and upheld the government's position that Earl was taxable on all that he had earned. In his brief opinion, Mr. Justice Holmes stated that "the statute could tax salaries to those who earned them and provide that the tax could not be escaped by anticipatory arrangements and contracts devised to prevent the salary when paid from vesting even for a second in the man who earned it." Does this mean that salaries are always taxable to the earner? Apparently not, because, not long after the Earl decision, the Court in Poe v. Seaborn ${ }^{43}$ held that in a community property state half the husband's earnings belong to the wife; so that he is taxable only on the other half.4

In view of the Seaborn case, the principle of the Earl case is not completely applicable to residents of community property states. It is, however, fully applicable to residents of other states, at least as to assignments of future earnings, ie., earnings which are contingent upon future services of the assignor. As to assignments of past earnings, the latest cases-in the Board and lower courts-are to the effect that where the assigned past earnings constitute a property right, and the assignor has completely

\footnotetext{
1281 U. S. 111 (1930).

"Supra note 33 , discussed infra, p. 251 .

"The husband's liability thus seems to turn on the question whether the division of income between himself and his wife stems from a statute or from a contract-a not wholly rational criterion.
} 
divested himself of such right without retaining any control over the income, such income when received is taxable to the assignee. ${ }^{4}$

In cases involving assignments of patent royalties ${ }^{40}$ and similar types of income, the test seems to be whether the assignor has transferred the property from which the income arises or merely the income itself; ${ }^{47}$ or, to employ the analogy suggested by Mr. Justice Holmes in the Earl case, whether he has parted with only the fruit, retaining the tree. If he has conveyed the tree, he escapes tax on the fruit. ${ }^{48}$ The recent case of Horst v. Commissioner ${ }^{49}$ appears to be an errant departure from this rule. In the Horst case, the taxpayer, who made his returns on the cash basis, detached the interest coupons from bonds and gave them to his son before they became payable, retaining the bonds themselves. It was held that the gift of the coupons relieved the assignor of tax. The court leaned heavily upon Blair v. Commissioner, where the life beneficiary of a testamentary trust irrevocably assigned interests in the trust income to his children and escaped tax on the assigned income. However, the Blair case seems distinguishable, for the taxpayer there owned only a life interest and completely divested himself pro tanto of that life interest. He could not retain, because he never had, control over the property which produced the income: the tree and the fruit were inseparable. The Blair case is easily reconcilable with the Earl case because of the element of control retained by Earl over the future income. However, when assignments of past earnings are involved; so that the element of control is missing, it appears sensible not to deny to a taxpayer who earned his income the privilege enjoyed by a taxpayer who inherits income or receives it from patent royalties. In either case, avoidance is implicit, but it is apparently avoidance of the type the law countenances.

A counterpart of attempts to assign income to relatives or trusts taxable as separate entities, in an effort to shift the income into lower surtax brackets, is the creation of a partnership or pseudo-partnership in which the taxpayer makes, or purports to make, his wife or other members of his family partners. Where there is a real partnership, i.e., where the wife or other relative enjoys the privileges and assumes the burdens of an actial partner; the device. works, for the statute makes the income of partnerships taxable to the partners. ${ }^{51}$ But where the putative partner does not have

\footnotetext{
"E Eubank v. Commissioner, C. C. A. 2d, Mar. 25, 1940; George O. Knapp, 40 B. T. A. 1144 (1939). Accord: Hall v. Burnet, 54 F. (2d) 443 (App. D. C. 1931), cert. denied, 285 U. S. 552 (1931). Contra on principle, though distinguishable on its facts: Van Meter v. Commissioner, 6r F. (2d) 817 (C. C. A. 8th, 1933).

"The Internal Revenue Bureau has attempted to distinguish patent royalties from "salary or earnings" (G. C. M. 19, 213, 1937-2, CuM. Bur. 220), but the distinction is specious. Patent royalties are just a much the result of services rendered-by the inventor-as are salaries.

${ }^{27}$ Nelson v. Ferguson, 56 F. (2d) 121 (C. C. A. 3d, 1932), cert. denied 286 U. S. 565 (1932); Julius E. Lilienfeld, 35 B. T. A. 391 (1937).

"Here, however, as in the Earl case, if the assignor's services are necessary to ripen the fruit, he will be taxable.

" I07 F. (2d) 906 (C. C. A. 2d, 1939). Accord: Rosenwald v. Commissioner, 33 F. (2d) 423 (C. C. A. 7 th, 1929), cert. denied, 280 U. S. 599 (1929).

${ }_{80} 300$ U. S. 5 (1937).

${ }^{62}$ Humphreys v. Commissioner, 88 F. (2d) 430 (C. C. A. 2d, 1937).
} 
the privileges or burdens of a true partner, she or he is rather merely an assignee of partnership profits and, under Burnet $v$. Leininger, ${ }^{52}$ the scheme fails.

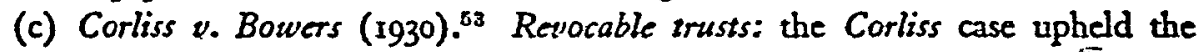
validity of an amendment to the 1924 Act making the income of a trust revocable by the grantor taxable to him. As in the Earl case, Mr. Justice Holmes wrote a concise opinion, the core of which is contained in the sentence: "The income that is subject to a man's unfettered command and that he is free to enjoy at his own option may be taxed to him as his income, whether he sees fit to enjoy it or not." He added that the case was too clear to need help from arguments based on the power of Congress to prevent escape from tax. ${ }^{54}$

As in many other instances, Congress in sealing up one loophole, unintentionally opened up others. The I9?4 Act provided that where a grantor at any time during the taxable year, either alone or in conjunction with any person not a beneficiary of the trust had power to revest in himself title to the trust corpus, the income was taxable to the grantor. Taxpayers soon realized that the italicized phrases constituted engraved invitations to aveidance, and their acceptance was immediate. The first italicized phrase gave birth to the so-called "year and a day trust." Under the terms of such a trust, the grantor's power to revest in himself title to the trust corpus was conditioned upon giving more than a year's advance notice of revocation. It was, therefore, argued, and with success, that there was no power to revest during the taxable year. ${ }^{\text {.5 }}$ Congress in the 2934 Act stopped up this opening by eliminating the words "during the taxable year."

The second of the italicized phrases, if interpreted literally, took the trust income out of the grantor's return where the trust was revocable (without his conjunction) by someone who was not a beneficiary but who for practical purposes would be under the grantor's control; or where the trust was revocable by the grantor in conjunction with someone whose beneficial interest was a minor one These loopholes were closed by the 1932 Act which changed the statute ${ }^{56}$ to its present form, i.e., the grantor is taxable if the power to revole is in him, either alone or with any person not having a substanisial adverse interest, or is alone in some person not having a substantial adverse interest. In Reinecke $v$. Smith, ${ }^{57}$ the Supreme Court held that a mere trustee was not a beneficiary; it follows that he has no adverse interest. In reaching this conclusion the Court gave great weight to the argument that a "contrary decision would make evasion of the statute a simple matter."

(d) Poe v. Seaborn (1930).58 Joint and separate returns of husband and swife: Spouses living together have had from the beginning of modern income tax law

285 U. S. 136 (1932).

281 U. S. 376 (1930).

"O'Donnell v. Commissioner, 64 F. (2d) 634 (C. C. A. 9th, 2933), cert. deried, 290 U. S. 699 (1933), indicated that the 1924 amendment was superfiuous, 2 view supported by the language quoted above.

"Iewis P. White, 56 F. (2d) 390 (D. M2ss. 2932); Langley v. Commissioner, 6r F. (2d) 796 (C. C. A. 2d, 1932). Cf. Helvering v. Clifford, infre p. 258, indicating that the taxpayers in these cases would have fared worse before the present Supreme Court.

"Revenue Aat of 1932, \$166; now INT. REv. COOE $\$ 166$.

15289 U. S. 172 (1933), interpreting the 1924 amendment.

* 282 U. S. IOI (1930). 
the privilege of filing either separate returns or else a joint return reporting their combined incomes. ${ }^{59}$ Where both have incomes reaching to the surtax brackets, the privilege of filing separate returhs is, for obvious reasons, quite a valuable one."0. But in nine states of the Union the privilege has acquired a premium value. These nine states ${ }^{61}$ have adopted what is known as the community property system.2 Under this system, all property acquired during marriage by the efforts of either spouse, together with the income therefrom, belongs to both spouses equally, even though one spouse, ordinarily the husband, controls and manages the community property. In the Seaborn case, involving citizens of the State of Washington, ${ }^{\text {es }}$ the government attempted to tax the controlling spouse (the husband) on the entire income of the community, but failed. The Court held that the wife had a vested property right in half the husband's income, and that the latter was, therefore, taxable only on the other half.

As a result of this decision, a husband and wife living in California ${ }^{\text {at }}$ with the husband earning say \$50,000 per annum-the couple having no other income-will pay about $\$ 3,400$ less tax than if they lived in New York. There is no appealing reason why the federal income tax should depend upon where the taxpayer lives; but all attempts to correct the situation have been blocked by Senators from the community property states. ${ }^{85}$ In 1921, an amendment actually passed the House which would have made the income of a marital community taxable to the controlling spouse. But, as might have been expected, the amendment died aborning in the Senate.

Of course, the advantage enjoyed by residents of community property states would vanish if all husbands and wives were compelled to file joint returns. Such a provision would also discourage inter-spouse gifts and trusts for avoidance purposes. The family unit seems to be a perfectly logical tax subject, and one common in other countries, notably Great Britain, where husband and wife are taxed on their combined income. The family unit will as a rule spend approximately the same amount for rent, food, support of children, etc, whether its income stems entirely from the husband or derives in part from the wife. Why should not their income tax bill likewise be the same? Hoeper v. Tax Commissioner of Wisconsin ${ }^{\text {g6 }}$ is thought by some to block the taxation of husbands and wives on their combined incomes. The case held (Justices Holmes, Brandeis and Stone dissenting) that a Wisconsin statute,

\footnotetext{
"This option can only be exercised to advanage where one spouse has deductions in excess of income, such excess being applied against the other's net income.

${ }^{80}$ Thus, a $12 x$ on one income of $\$ 50,000$ would be about $\$ 9,000$, while the aggregate tax on two incomes of $\$ 25,000$ each would be unly about $\$ 5,600$.

"1 Arizona, California, Idaho, Louisiana, Nerada, New Mexico, Oklahoma, Tcxas, and Washington. In Oklahoma, the most recent convert to the community property system, husband and wife apparenty have an option whether they will be governed by the system. Note (1939) 17 TAx Magnzane 482.

"2 Pali aso Mertens, Lat of Federal Income Taxation (1934-35) 316.01.

" There were later Supreme Court decisions with respect to other community property states.

- After California became an out-2nd-out community property state, it attracted a considerable number of motion picture stars and other high-salaried talents. Its federal income tax advantage also permits the state to impose higher rates of saie income tax than non-community stater.

"GrEes, op-cir. supra note 6, at 51. "294 U. S. 215 (1932).
} 
which apparently taxed the husband on the combined incomes of himself and his wife, was unconstitutional: "Any attempt by a state to measure the tax on one person's property or income by reference to the property, or income of another is contrary to due process of law as guaranteed by the Fourteenth Amendment." However, the Court has traveled a long road since the Hoeper case. The views of what was then a minority are now the shibboleths of the majority. At any rate, the Hoeper case could be distinguished ${ }^{07}$ in testing a federal statute requiring a joint return by husband and wife living together, each spouse to pay a ratable part of the tax proportionate to his share of the income. This would eliminate not only the income tax advantages enjoyed by residents of community property states but also the tax disparity between families where the husband is the sole source of income and families where the wife contributes.

(e) Burnett v. Wells (1933). ${ }^{88}$ Irrevocable trusts for the benefit of the grantor: From a constitutional law viewpoint, the Wells case is the most important case touching the subject of tax avoidance. It demonstrates, although by the barest possible margin, ${ }^{60}$ that, when it comes to preventing income tax avoidance, Congress may go to almost any length before it reaches the brink of unconstitutionality. ${ }^{70}$ The case involved the validity of the provision, ${ }^{71}$ first enacted in 1924 , which taxes the grantor on the income of a trust if such income is or may be used to pay premiums on policies insuring his life. ${ }^{72}$ Wells had created irrevocable trusts to which he transferred securities the income from which was to be applied to the payment of premiurns on certain policies insuring his life. The beneficiaries of the policies were persons for whom he would normally have provided in the event of his death, a daughter, sons, relatives and an employee who later became his wife. So far as appears from the reports of the case, Wells retained none of the incidents of ownership in the policies. ${ }^{73} \mathrm{He}$ retained no control over the trust property, nor was the income used to discharge any of his legal obligations. Wells, of course, argued that the statute, insofar as it authorized taxing him on the income from property that was no longer his, infringed the Fifth Amendment. The Court majority of five, speaking through Mr. Justice Cardozo, rejected this argument. The majority's conclusion rested on a number of grounds, but the basic one appears to be that the maintenance of life insurance for the benefit of dependents is "a pressing social duty," "a common item in the family budget"; and "Congress does not play the despot in ordaining that trusts for such uses ... shall be treated for the purposes of taxation as if the income of the trust had been retained by the grantor."

Mr. Justice Cardozo reviewed the preceding steps of Congress and the courts to prevent avoidance, and observed that the provision in question was "of a piece" with "the progressive endeavor of Congress and the courts to bring about a correspondence

\footnotetext{
" But cf. MAgill, TAXABLE INCOME (1936) 290-292.

as 289 U. S. 670 (1933).

ro $\mathrm{Cf}$. the cases cited supra note 39 . ${ }^{71}$ Now INT. Rev. CODE 5167.

${ }^{72}$ The section also provides that the grantor is taxable if the income can, in his discretion, be distributed to him or be accumulated for him.

" But see, as to certain of his accident policies, 63 F. (2d) 425,442 (C. C. A. 8 th, 1933).
} 
between the legal concept of owncrship and the econcmic realities of enjoyment or fruition." This, in the writer's view, was the more compelling reason for the Court's conclusion. The use of funded insurance trusts as a tax avoidance device was widespread, and the statute was palpably necessary to prevent such avoidance.

Having sustained the imposition of tax based on the satisfaction of a social obligation, the Court found it easy, even without the aid of a clearly expressed statutory provision, to tax the grantor on trust income used to discharge his legal obligations. Thus in Douglas $v$. Wilcutts, ${ }^{74}$ the income of an alimony trust was taxed to the grantor husband, where the trust, approved by the divorce decree, was merely security for his continuing obligation to support his divorced wife. ${ }^{78}$ The same result was reached as to income of a trust used to support and maintain minor children of the grantor whom he was under a legal obligation to support. ${ }^{70}$ Similarly, the grantor is taxable on trust income which is used to satisfy his ordinary debts (other than obligations to support). ${ }^{77}$

(f) Gregory v. Helvering (1935).$^{78}$ Tax-free exchanges: If the Wells case is the high spot in tax avoidance law from the constitutional law viewpoint, the Gregory case is the important highlight from the angle of statutory interpretation. In it the Court was required to construe the meaning of the tax-free reorganization provisions of the 1928 Act. Beginning with the 1918 Act, Congress, realizing that tax on a mere change in the form rather than the substance of property, as where stock in Corporation $A$ of New York was exchanged for stock of Corporation $A$ of Delaware (the latter acquiring all the assets and assuming all the liabilities of the former), was both a hardship and a deterrent to normal readjustments of corporate structures, began to enact provisions designed to permit tax-free exchanges; or rather to postpone the tax until a gain was realized in cash or property substantially different from the original property. In I92I, the provisions were so liberalized that they immediately became the prevalent avoidance vehicle. ${ }^{79}$ The reverse process began with a special Act in 1923, and the legislators and the courts ever since have been narrowing the applicability of the provisions until today their employment for avoidance purposes is extremely difficult, although not impossible. By 1928, the year involved in the Gregory case, a number of loopholes had been blocked up, but not all. The law in that year ${ }^{80}$ permitted the distribution to a stockholder, without recognition of taxable gain, of stock or securities in a corporation a party to a reorganization. Mrs. Gregory,

${ }^{24} 296$ U. S. I (1935). USe Paul, Five Yea; with Douglas w. Willcuts (1939) 53 Harv. L. Rev. I.

T5 Where the alimony trust is not merely security but a complete discharge of tie obligation to support, the result may be different. Helvering v. Fuller, 60 Sup. Ct. 784 (1940). Cf. Helvering v. Fitch, 60 Sup. Ct. 427 (1940) and Helvering v. Leonard, 6o Sup. Ct. 780 (1940).

${ }^{70}$ Helvering v. Schweitzer, 296 U. S. 551 (1935); Helvering v. Stokes, 296 U. S. 55I (1935). Where the trust income is not actually expended for the minor's support, and discretion as to its use is in someone other than the grantor, it is not taxable to the grantor. J. S. Pycatt, 39 B. T. A. 774 (1939), distinguishing E. E. Black, 36 B. T. A. 346 (19,37).

${ }^{77}$ Helvering v. Blumenthal, 296 U. S. 552 (1935).

783 U. S. 465 (1935).

30 For the history of these provisions, see Report of a Subcommittee of the House Ways and Means Committce (dated Dec. 4, 1933) 73d Cong., 2d Sess., pp. 37-42. This subcommittee made out a strong case for the abolition of the provisions.

${ }^{80}$ Revenue Act of $1928 \$ 122(\mathrm{~g})$. 
who owned all the stock of a personal holding company, United Mortgage Company, desired to sell, with a minimum of tax liability, stock of Monitor Securities Corp. owned by United. She arranged for the organization of a new corporation, Averill. The latter acquired the Monitor shares in exchange for its own stock, which was issued directly to Mrs. Gregory. Averill was dissolved a few days later, and Mrs. Gregory received in liquidation thereof the Monitor shares she desired to sell. On sale of these shares she contended she had received them tax-free from United and was subject to tax only on the excess of the proceeds of sale over a pro rata portion of her cost basis for United stock; but the government maintained that she had in substance received a taxable dividend from United in the form of the Monitor shares. ${ }^{81}$ Within the literal meaning of the statutory definition, each step in the technically perfect scheme whereby Mrs. Gregory acquired the Monitor shares was a tax-frce reorganization. But the Court refused to interpret the statute literally. It brushed aside the "elaborate and devious" form of the transaction as a masquerade for a reorganization and upheld the government's position. In doing so, it specifically excluded from consideration the question of motive-avowedly avoidance-and rested its conclusion on the ground that the statute meant by reorganization a transaction in furtherance of the reorganized corporation's business; and that measured by this test the scheme was outside the plain intent of the statute. Thus the Court interpolated into the Congressional definition something not written there, viz., the requirement of business purpose.

Later, the Court wove into the legislative definition of a reorganization still another condition not to be found on the statute's surface: a requirement that the transferor retain a substantial stake in the enterprise. ${ }^{82}$

(g) Helvering v. National Grocery Co. (1938). ${ }^{83}$ Improper accumulation of earnings by corporations. One of the most troublesome methods of tax avoidance has been, and still is, the accumulation of corporate earnings. Since the beginning of the modern income tax era (1913) the rates of corporate tax have been lower than the individual rates (except in the lower brackets), with the result that an individual who incorporates his business and accumulates all or part of its income is subject to a lesser burden than if he were unincorporated. ${ }^{84}$ Congress foresaw this possibility from the very start, and in 1913 empowered the Commissioner to tax shareholders on the undistributed income of the corporation where non-distribution was motivated by a desire to save the shareholders from the surtax rates. In rg20, Eisner v. Macom$b_{e}{ }^{85}$ cast doubt on the validity of thus taxing shareholders; and a weak-kneed Congress abandoned the method and in lieu of it imposed a penalty surtax on the cor-

\footnotetext{
${ }^{n}$ Mrs. Gregory asserted that her gain on the sale of the Monitor shares was $\$ 76,000$, most of it taxable 2t the capital gains rate. The government maintained that she had received a dividend of $\$ 133,000$ subject to ordinary surtax sates. 27 B. T. A. 223 (1932).

"The stake must be a proprictary one rather than that of a creditor or bondholder. LeTulle $v$. Scoficld, 308 U. S. 415 (1940). See Helvering v. Bashford, 302 U. S. 454 (1938); Groman v. Commissioner, 302 U. S. 82 (1937).

"The maximum saving based on current rates is $61 \%$.

252 U. S. I89 (1920), supra nate 38 .

304 U. S. 282 (1938).
} 
poration itself. The constitutionality of this later method, which prevails to this day, ${ }^{86}$ was upheld by -the Supreme Court in the National Grocery Co. case.

Liability to the penalty tax turns on the purpose, i.e., the motive behind nondistribution. This test, however, is subjective and suffers from the inherent infirmitics of such a touchstone. Consequently, the statute aids the government with certain presumptions; the fact that the company is a mere investment or holding company ${ }^{87}$ is prima facie evidence of the prohibited purpose; while accumulation of carnings beyond reasonable business needs is determination of that purpose, unless the corporation clearly proves to the contrary. But, even with these presumptions, the statute has not been very successful. In $193^{6}$ Congress attempted to solve the problem when it imposed a surtax on undistributed profits regardless of the reason for nondistribution. This proved to be extremely effective; ${ }^{88}$ but political pressure forced its repeal.

The highest rate of penalty surtax is $35 \%$, and hence the section loses most of its effectiveness when the income of those who control the company falls in brackets above the $35 \%$ level. The writer has elsewhere ${ }^{89}$ recommended a return to the original method of taxing the shareholders-with certain modifications to close up loopholes in the original method. The government could then effectively pursue those stockholders who were responsible for non-distribution without penalizing those who were innocent; and the $35 \%$ limitation would no longer be a barrier to the section's efficacy.

In upholding the section in the National Grocery Co: case, Mr. Justice Brandeis, speaking for the majority, said that the sole owner of a business could not, by conducting it in corporate form, prevent Congress, if it chose, from taxing him individually on the year's profits. This statement foreshadows the validity of provisions enacted in 1937 to tax shareholders of foreign personal holding companies on the undistributed income of such companies.

(h) Griffiths v. Helvering (1939). ${ }^{.0}$ Instalment sales: Since the enactment of the rg26 Act, the law has contained an ameliorative provision giving the taxpayer an election, in certain cases, to spread the gain from the sale of property over the period of collection of the proceeds of sale, ratably according to the amount collected each year. ${ }^{91}$ Under current law, the privilege is available only if the payments received from the vendee during the taxable year in which the sale occurs do not exceed $30 \%$ of the selling price. Here is an example of permissible avoidance. If an individual, •

\footnotetext{
${ }^{20}$ INT. REv. CODE $\mathbf{S}$ roz. The historical development of the section is reviewed in Rudick, Section roz and Personal Holding Company Provisions of the Internal Revenue Code (1939) 49 YALE L. J. 173 et seg. The validity of the original method was never really tested in the courts.

${ }^{87}$ For the special taxes imposed on domestic and "forcign" personal holding companies, sce id, at 202 et seg.; Sutherland, A Brief Description of Federal Corporation Taxes, infra at pp. 273-278, passim.

80 Rudick, supra note 86, at 217.

"Id. at 218.

${ }^{\circ 0} 308$ U. S. 355 (1939).

- Treasury Regulations which, even prior to the statutory provision, had permitted use of the instalment basis for reporting gain on such sales, were held invalid by the Board of Tax Appeals. Report of the Senate Finance Committee on the 1926 Revenue ACt, SEN. REP. No. 52, 6gth Cong., '1st Sess. (1926) 32-33.
} 
in December of 1939 , sells for $\$ 300,000$ in cash real estate which cost him $\$ 200,000$, the entire gain of $\$ 100,000-$ subject to the capital gain provisions of the law-must be reported for 1939. But if his contract calls for payment to him of $\$ 90,000$ in December and the remaining $\$ 210,000$ on January 2, 1940 only $\$ 30,000$ of the gain need be. reported for 1939 and the remaining $\$ 70,000$ will be includable in 1940 income. Thus, by a slight rearrangement, he can appreciably reduce his tax..$^{02}$

The taxpayer in the Griffiths case sought to take advantage of the optional method just described. In 1926 he had purchased some stock for $\$ 100,000$ from one Lay. The investment turned out unprofitably and in $193 \mathrm{I}$ he had been allowed the loss. In 1932, Griffiths discovered that he had been defrauded by Lay in purchasing the stock, and after negotiation, Lay agreed in 1933 to buy it back from him for $\$ 100,000 \mathrm{cash}$, in effect rescinding the original transaction. Having been allowed the loss in $1931,{ }^{93}$ Griffiths realized that the repurchase by Lay would result in taxable gain. He therefore attempted to convert what was actually a cash sale into an instalment sale, organizing a new wholly controlled corporation to which he purported to sell the stock for $\$ 100,000$, largely payable in annual instalments over a period of forty years. This corporation then purported to sell the stock to Lay for $\$ 100,000$. Lay did not know of the corporation and assumed throughout that he was repurchasing the stock from Griffiths. Griffiths transferred the stock to Lay, gave him a general release and received the $\$ 100,000$, which he turned over to the corporation.

The government disregarded the existence of the newly organized corporation and taxed Griffiths as if he had personally made a sale for cash. The Court, adopting a realistic view of the transaction, sustained the government's position. Mr. Justice Frankfurter, speaking for a unanimous Court, reiterated the remark made in the Corliss opinion that "taxation is not so much concerned with the refinements of title as it is with the actual command over the property taxed-the actual benefit for which the tax is paid" and added that it makes no difference that such command may be maintained through the medium of a subservient agency.

(i) Higgins v. Smith (1940).94 Artificial losses: A common use of the corporate entity prior to 1934 as a tax-avoiding device was the sale to a controlled corporation of securities at a loss, which reduced the tax otherwise payable by the individual stockholder. Of course, the sale had to be bona fide; and a repurchase of the securities from the corporation generally vitiated the scheme. The law was expressly amended in 1934 to close the loophole; but, according to the $S$ mith case, the amendment was superfluous in the case of a company owned by a single stockholder. Smith, prior to I934, had sold securities to a wholly owned corporation at a loss which he claimed in his individual return. The Court majority, overriding the decisions of four circuit courts of appeal, ruled that the domination and control of the stock-

\footnotetext{
02 In 1928 a loophole was closed when Congress provided that on the death of a taxpayer who had availed himself of the provisions, the untaxed profit should be included in his final return unless his estate or heirs agreed to take up such profit in their returns.

${ }^{98}$ Griffiths' loss in 1931 was apparently realized by sale to a controlled corporation. In view of the Smith case, discussed infra, this loss would appear to be unallowable.

${ }^{\circ} 308$ U. S. 473 ( 1940 ).
} 
holder in such a corporation is so obvious "as to require a peremptory instruction [to the jury] that no loss in the statutory sense could occur upon a sale by a taxpayer to such an entity." ${ }^{25}$ Mr. Justice Reed's reasoning is not convincing, principally because the legislative history of the 1934 amendment (reviewed by Mr. Justice Roberts in his dissent) clearly indicates that Congress thought it was changing the law when it enacted the amendment. The majority opinion suggests that Congress had intended merely to expand the disallowance to cases where the selling stockholder controlled the buying corporation but did not own all of its stock. However, the dissenting opinion, in which Mr. Justice McReynolds concurred, seems more persuasive.

In the $1937 \mathrm{Act}$, the restriction against losses on transactions between family members and between an individual and a controlled corporation was further strengthened; but a few openings are still left, at least if the letter of the law is to govern. For example, a loss on a sale from one company to another, neither being a personal holding company, would still be deductible even though both companies were controlled by the same stockholder. Presumably, if both companies were entirely owned by him, the Smith case would apply and the loss would not be deductible. A sale of stock by an individual on the Stock Exchange and an immediate purchase of other shares of the same stock by his controlled corporation would still apparently give rise to a deductible loss, ${ }^{97}$ despite the wash sales provision, ${ }^{98}$ first enacted in 1921, which prohibits the deduction of loss on the sale of securities if within thirty days before or after the sale, the taxpayer has purchased substantially identical securities.

(j) Helvering v. Clifford (1940).98 Irrevocable term trusts: As scon as taxpayers learned that revocable trusts were no longer a haven from income tax and that the price for retaining beneficial control over the trust res or its income would be taxation on such income, they concluded that half a loaf was better than none and began to create irrevocable trusts over which they retained a non-beneficial control. In such trusts the object is to make the control nominally non-beneficial, but to have the grantor retain, for practical purposes, as much control as the income tax law will permit. For instance, a grantor sets up an irrevocable trust for the term of his life, the income to be paid to $A$, with power in the grantor to change the beneficiary at any time, except that neither the grantor nor his estate may be an income beneficiary. It has thus far'been held that the grantor of such a trust is not taxable on the trust income. ${ }^{100}$ But why should he not be? His power to change the beneficiary constitutes a whip to make the current beneficiary conform to the grantor's wishes, and hence amounts to virtually the same control over the income as is present in a revocable trust.

\footnotetext{
"2 Mr. Justice Reed distinguishes Burnet จ. Commonwealth Improvement Co, 287 U. S. 415 (1932), holding taxable a profis on 2 sale of securities to 2 wholly onned corporation.

${ }^{\circ}$ But of. Shoenberg r. Comm'r, 77 F. (2d) 446 (C. C. A. 8th, 1935). Except for brokerage commissions and a possible gain or loss on the repurchase, this transaction is not materially different from a direct sale to the corporation.

"INT. Rev. CoDe 5118.

${ }^{200}$ Krapp v. Hocp, 104 : (2d) 99 (C. C. A. 2d, 1939); Ellsworth R. Buck, 4I B. T. A. J2n. 18, 1940. But $f$. Helvering v. Clifford, supre note 99.
} 
Another and more common trust of this type is the short-term trust. Its grantor usually provides that it shall last a definite number of years, generally not more than ten, ${ }^{101}$ during which the income is to be paid to someone else; and at the end of the specified term or on the death of the beneficiary, if that occurs first, the trust corpus is to revert to the grantor. Or a remainderman "other than the grantor may be named with a proviso that if the named remainderman dies before the trust terminates, the trust corpus is to revert to the grantor. Thus far it has generally been held that the grantor's remainder, or possibility of reverter, is not of itself suffcient to make him taxable on the trust income. ${ }^{102}$ In the absence of a specific statutory provision, this view seems sound, although Helvering $v$. Hallock ${ }^{103}$ casts some doubt upon its correctness. The Hallock decision held that for estate tax purposes, a possibility of reverter in the grantor may suffice to require the inclusion of the trust corpus in his gross estate; conceivably the scope of this principle will be extended to embrace income tax liability.

Regardless of whether a mere remainder or possibility of reverter will ipso facto tax the grantor on the trust income, it is now established by the Clifford case that the retention of such an interest, coupled with other attributes of ownership, may justify taxing him as the owner of the trust property-not under the specific provisions of Sections 166 and 197 of the Code, but under the elastic provisions of Section 22(a) defining gross income. In the Clifford case, the taxpayer had declared himself trustee of certain securities. The trust was for a five-year period, terminating sooner upon the death of either the grantor or his wife. The trust income was to be held for the wife's exclusive benefit; and, although the grantor had absolute discretion as to the amount to be distributed to her, any amount undistributed at the trust's termination was to be her separate property. The grantor retained wide powers of management and control. The basis for the decision holding the grantor taxable on the trust income under Section 22(a) is summed up by the following paragraph from the majority opinion written by Mr. Justice Douglas: "In this case we cannot conciude as a matter of law that respondent ceased to be the owner of the corpus after the trust was created. Rather, the short duration of the trust, the fact that the wife was the beneficiary, and the retention of control over the corpus by respondent, all lead irresistibly to the conclusion that respondent continued to be the owner for purposes of Section 22(a)."

The opinion describes the trust as "at best a temporary reallocation of income. within an intimate family group" and makes it clear that "no one fact is normally decisive, but that all considerations and circumstances of the kind we have mentioned are relevant to the question of ownership and are appropriate foundations for finding on that issue." Accordingly, the grantor's liability for tax on the income of an irrevocable term trust apparently depends upon a composite of three factors:

${ }^{101}$ A trust need not be for a term of years to be, in effect, 2 short-term trust: it may be for the life of a very aged person whose life expectancy is brief.

${ }^{20 s}$ Meredith Wood, 37 B. T. A. 1065 (1938) affd, 104 F (2d) 1013 (C. C. A. 2d, 1939), affd, 60 Sup. Ct. 551 (1940); William Bocing, 37 B. T. A. 178 (1938), rev'd on another point, 106 F. (2d) 305 (C. C. A. gth, 1939). ${ }^{103} 60$ Sup. Ct. 444 (1940). 
(1) the term of the trust; (2) the relationship of the beneficiary to grantor; and (3) the degree of control retained by the grantor over the trust property.

Recently there has been a growing use of irrevocable trusts in which the income is made payable semiannually on January 2 and July 2 to the designated beneficiary if living at that time and, if not living, then to some other person. The idea behind such a trust is that the income for the last half of the year, being for the benefit of an unascertained person or a person with a contingent interest, ${ }^{104}$ will be taxable to the fiduciary, while the income for the first half will be distributed and taxable to the beneficiary. Thus the income is split into two heaps instead of one, and the surtar lessened. So far, this device bas been successful ${ }^{105}$ and the Bureau of Internal Revenue has even acquiesced-after some vacillation-in the decisions upholding it. However, it is hard to see why, if the grantor may be taxed on income which he never receives, as in the Clifford case, the beneficiary should not be taxed on income actually paid to him-although in the next taxable year-just because there was a bare chance that it might not have been.

\section{The Judicial Ammitde in Ixcose Tax Avoidance Cases}

Is it possible from a study of the Supreme Court cases discussed above to crolve a rule or set of rules which will help us to find out what kinds of avoidance are permissible and what kinds are taboo? To what extent will form-as distinguished from substarce-shield us against tax? Why should an individual be denied 2 loss on a sale of stock directy to his wife, when, if he were to sell the stock on the Stock Exchange and she were immediately thereafter to purchase the same kind of stork, the loss would be allowable? Why should a husband and wife be able to reduce the family's income tax bill by moving across a state line? It is implicit in questions such as these that there are two kinds of avoidance, one of which the law countenances, and the other of which it forbids. If we are to even attempt to ascertain where permissible avoidance ends, we must have a starting point; and we can do no better than begin ${ }^{108}$ with Mr. Justice Holmes' "line theory."

(a) Holmes' Line Theory: The late Mr. Justice Holmes was one of those who recognized that most legal distinctions are questions of degree and that it is necessary to draw a line somewhere to separate the good from the bad. ${ }^{107}$ So far as tax avoidance is concerned, this idea is nowhere better expressed than in Bullen $v$. Irisconsin, ${ }^{108}$ a case involving the constitutionality of the Wisconsin inheritance tax on the corpus of a trust established in Illinois by a Wisconsin decedent (presumably to avoid the Wisconsin tax). Said Mr. Justice Holmes: "We do not speak of evasion, because, when the law draws a line, a case is on one side of it or the other, and if on the safe side is none the worse legally that a man has availed himself to the full of what the law permits. When an act is condemned as an evasion what is

ING INT. REv. CODE \$16r(2)(x).

${ }^{30 x}$ Commissioner v. Desn, 102 F. (2d) 699 (C C A. roth, 1939) aff'B. 35 B. T. A. 839 (1937); Augustus H. Eustis, 30 B. T. A. 820 (1934).

200 As did Mr. Paul, op. cit. supre note 8, at 200.

201 Id. at 100-104, and footootes thereon

${ }^{100} 240$ U. S. 625 (1916). 
meant is that it is on the wrong side of the line indicated by the policy if not the mere letter of the law."

In the light of recent decisions, the cornerstone of this philosophy is found in the phrase "the policy ... of the law." It is now clear that the letter of the law is not a reliable guide. ${ }^{100}$ Nowhere in the letter of the law is there anything that expressly makes the grantor of an irrevocable trust taxable on income payable to the beneficiary (Clifford); nowhere in the law is there anything that specifically says the grantor of an alimony trust (Douglas) or a trust for the maintenance of minor children (Schweitzer and Stokes), or a trust for the payment of the grantor's debts (Blumenthal) is taxable on the income of the trust. Nowhere, prior to 1934, was there a word in the statute to indicate that a loss on the sale of property to a wholly owned corporation was not allowable (Smith). Nowhere in the law was, or is there, a provision requiring a reorganization to have a business purpose to qualify as such within the ?eaning of the statute (Gregory), or that the transferors in such a reorganization must have a continuing proprietary interest in the assets transferred (Groman, Bashford, LeTulle). It was the policy of the law that the Court invoked in these cases, not its letter. In some of these cases, e.g., Gregory, Smith, Clifford, the Court was undoubtedly legislating. But, if we are to advise our clients intelligently, it will do no good to wail that this is not the Court's function. The courts do legislate, as has frequently been pointed out, and the point where interpretation ends and legislation begins is difficult to find. ${ }^{110}$

The vitality of Holmes' line doctrine has not been impaired by recent decisions. It is still sound. But there are a couple of corollary propositions that must be taken into account. The first of these is that the wrong side of the line is so heavily magnetized that a case which approaches the line is likely to be drawn over to that side. The second is that the policy of the law may change while the letter remains the same. The change in policy may proceed not only from a revised administrative practice $^{111}$ but as well from a difference in attitude on the part of the Supreme Court. ${ }^{12}$ Heretofore it has been the policy of the law, expressed in the Seaborn case, that a married couple in a community property state may, by filing separate returns, avoid some of the burdens they would have to shoulder if they resided in another state. But the Clifford case indicates that if the question were presented to the present Court, the policy of the law might change. The task, then, is to determine the current policy of the law; and it may help us in our task' if we can separate the cases into groups.

100 There are, of course, exceptions. Note, e.g., Koshland v. Helvering, 298 U. S. 441 (1936).

${ }^{120}$ Mr. Paul makes the point, to which most will agree, that "judge-made law should stop short of overruling legislative law." Selected Studies in Federat Taxation (2d Serics 1938) 185, note 105. Sometimes the Supreine Court's construction, does not accord with the intent of a contemporaneous Congress which overrides the judicial legislation, e.g., U. S. v. Hendler, 303 U. S. 564 (1938); Koshland r. Helvering, 298 U. S. 44I (1936); and May v. Heiner, 281 U. S. 238 (1930). See note 7 in opinion by Mr. Justice Frankfurter in the Hallock case, supra note 103.

${ }_{212}$ Helverieg v. Wilshire Oil Co., 308 U. S. 90 (1939). Cf. Helvering v. R. J. Reynolds Tobacco Co, 306 U. S. 110 (1939).

${ }_{112}$ See note 23, supra. 
(b) Classification of income tax avoidance cases: The cases discussed herein can be broadly classified into two groups: (I) cases in which an individual shifts income to some other individual in a lower bracket with the idea of avoiding tax; -(2) cases in which no such shift is attempted, but in which a controlled or subservient agency or conduit is interposed between the individual and his income either as a shield against the tax or as a vehicle for an artificial deduction. In the first group fall cases like Taft, Earl, Poe, Corliss, Wells and Clifford; in the second, cases like Gregory, National Grocery Co., Griffiths, and Smith.

In the first group, the key word is "ownership" or rather the tax concept of ownership: Has the economic position of the transferor changed so materially that it would be unreasonable to treat him as still the owner of the property for income tax purposes? To state it differently: Has the taxpayer relinquished enough of the attributes of ownership so that it would be despotic to tax him as the owner? In answering the question, the approach must be a realistic one; but motive is apparently not a controlling factor, though it may be a contributing one. The problem remains, however, one of degree. To illustrate, consider possible variations of the situation disclosed in the Clifford case.

We now know that the grantor of an irrevocable trust will be taxable on its income if there is the following concatenation of circumstances: (I) trust for five years or until the prior death of grantor or beneficiary; (2) grantor's wife (living with him) the beneficiary; (3). trust corpus reverts to grantor on termination; (4) grantor the sole trustee; (5) trustee has broad powers of management and control. Suppose we vary only the first of these circumstances, and provide that the trust will last for ten years and both grantor and wife have a reasonable expectancy of living that long. Will this change the result? Probably not: the grantor still retains a sufficient measure of control over the property to justify taxing him as if he were the owner. Next, suppose we change only the fourth circumstance and make a trust company the trustee; or vary the fifth circumstance and restrict the powvers of the trustee. Will these changes compel a different result? Possibly, but not certainly. Or suppose we modify only the third circumstance and provide that the trust corpus shall not revert to the grantor, or alter only the second circumstance so that the beneficiary is a stranger. We are in either of these last two cases further away from the wrong side of the line, but the distance is still uncomfortably short. Even if we modify each of the first two conditions in the manner stated, we may still be perilously close to the line. But if we vary each of the first three in that manner we should be far enough away so that the magnetic attraction of the wrong side of the line should have no effect; and, if we change all five, the quicksands are far behind us.

In the second group of cases, the question of ownership is absent. The transaction has not changed the economic situation of the taxpayer. What he formerly held in his right hand is now contained in his left; or what he formerly owned in one shape, he now owns in another. The touchstone here seems to be in the words "subservient agency."113 If the instrument relied on to shicld the taxpayer against the tax, be it a

${ }^{112} \mathrm{Mr}$. Justice Frankfurter in Griffths v. Helvering, supra note 90. 
corporation or some other taxable entity, is real rather than a sham and if it is not merely the alter ego of the taxpayer, it will serve him in good stead. Otherwise it will prove paper-thin. In this group, too, the approach must be a realistic one, but here the question of motive is more material, despite the disclaimer of Mr. Justice Sutherland in the Gregory case. Again the problem is one of degree-the measure of vassalage or subserviency of the agency or conduit employed. For illustration here, let us use the Smith case.

An individual sells at a loss to his wholly owned corporation. The loss is not allowable even in the absence of a specific provision forbidding the deduction. But suppose he sells to a corporation of which he owns only $90 \%$ of the stock. Is this sufficient to alter the result? Probably not. The subserviency of the agency used is pretty obvious, especially if the minority stock is owned by a member of the taxpayer's family. If we go further and assume that the seller owns only $51 \%$ and that the remaining stock is not owned by a close relative, what then? His control of the corporate instrumentality is so marginal that it can hardly be characterized as subservient, and there seems to be no sound reason why, in the absence of statutory prohibition, ${ }^{114}$ the loss should not be allowed. To ge in the other direction, assume that the individual sells stock on the Stock Exchange and his wholly owned corporetion immediately thereafter buys other shares of the same stock. The wash sales provisien of the statute does not specifically cover this situation, but it is entirely conceivable, in view of the Smith case, that the courts will rule that the policy of the law extends to such a transaction, even if its letter does not. The danger will diminish, of course, in inverse ratio to the percentage of stock owned by the controlling stockholder.

To recapitulate, the judicial atitude toward income tax avoidance may be summed up as follows: When Congress has spoken clearly, anything it says will be upheld as constitutional, if reasonably necessary to prevent avoidance. If there is any doubt as to the intent of Congress, a particular method of avoidance will not be sustaired unless support for it is found not merely in the letter of the law, but in its policy as well. "Legislative words are not inert, and derive vitality from the obvious purposes at which they are aimed."118 In each of the two groups of cases mentioned, the judicial approach will be a realistic one: forms are likely to prove a poor shelter against tax. In each group, the problem is one of degree: where shall the line be drawn?

We carnot predict exactly where the line will be drawn, but we know what it is that attracts us to the line. In the first group, it is the measure of ownership that remains in the taxpayer; and, in determining this, traditional legal concepts of property are dumped overboard, to be replaced by the recent tax concept of a family economic unit. In the second group, the attracting force is the degree of subserviency of the instrument employed.

216 The current statute definitely forbids suxh a deduction, \$24(b).

${ }^{218} \mathrm{Mr}$. Justice Frankfurter in Giffihs v. Helvering, supre note go. Cf. the fomous music amlogy by Judge Learned Hand in the Gregory case, 69 F. (2d) 809,811 (C. C. A. 2d, 1934): "A melody is more than the notes" 


\section{Conclusion}

If history ${ }^{116}$ is any guide to the future, we may hazard some conclusions:

(I) Randoiph Paul's conclusion as to the attitude for the lawyer in tax avoidance casés is strikingly sustained by the latest cases. It cannot be better stated than in his own words: $: 117$

"Whatever may be the penalty for audacity in other fields of law, a lawyer has no right to venture into the law of tax avoidance without being inoculated with the cynical acid of distrust. If he is not a skeptic, he is a child. He must have no faith. He must discount everything he reads. It may be emotional claptrap, a sermon on the duty to pay taxes, a particular case, or verbal agility rationalizing subconscious predilections. He must warch for inarticulate law. If he reads with trust, he is as lost as a babe in the woods. He must read between the lines, catching the overtones. The true message in lax avoidance cases will hardly ever be found in the mere words employed, but only in a free translation which does justice to that which is not, and perhaps cannot be, written."

(2) Tax avoidance may be in the twilight but the night is still far off. The law openly or tacitly countenances certain types of avoidance; and it is perfectly legitimate to take advantage of these types. But permissible avoidance is steadily diminishing and is likely to go on diminishing under the present revenue needs. Non-permissible avoidance is also dwindling as taxpayers come to realize that questionable avoidance rarely pays nowadays.

(3) Division of income among the members of a family as a tax saving device has no equitable basis. The law should be changed to require husbands and wives and minor children living together to file a composite return. Without doubt this would eliminate the greater part of questionable current avoidance, and would remove the unjustified tax differential between citizens of community property states and those of other states. If the enactment of such a law is politically impracticable because of opposition by Senators from the community property states, the Treasury should revive the atrempt which failed in the Seaborn case.

(4) The Treasury Department's realistic attitude toward tax problems, and that of the courts as well, should extend not only to transactions involving avoidance, but 2lso to transactions in which, but for form, there would be no tax. One of the taxpayer's most cogent reasons for circumventing the law if possible is that the Treasury seldom fails to interpret the law literally when such interpretation produces tax, even if injustice results. ${ }^{118}$ The Treasury's answer is that it does not make the law; it merely administers it. But this is a rather lame excuse. If the government's fiscal officers may expand the letter of the law to secure their just due, there is no reason why they should be bound by a blind adherence to that letter when such a course would produce injustice-except, of course; when there is not the slightent doubt of legislaxive intent.

\footnotetext{
210 "A page of bistory is worth a volume of logic" Mr. Justice Holmes in Nen York Trust Ca v. Eisner, 256 U. S. 345, 349 (1921).

121 Paun, 0p. cil. supre nove 8, at 99.

${ }^{130}$ Note, e.8., I. T. 3334, 1939 INT. Rev. Burl. 45, p. 5; or Crane-Johnson Co. r. Commissioner, 105

F. (2d) 740 (C. C. A. 8th, 1939), cert. granked, 308 U. S. - 60 Sup. C. 386.
} 
In United States v. Merriam, ${ }^{119}$ the Supreme Court quoted Lord Cairns' understanding of the principle of all fiscal legislation as follows:

“... If the person sought to be taxed comes within the letter of the law, he must be taxed, however great the hardship may appear to the judicial mind to be. On the other hand, if the Crown, seeking to recover the tax, cannot bring the subject within the letter of the law, the subject is free, however apparently within the spirit of the law the case might otherwise appear to be. In other words, if there be admissible in any statute what is called an equitable construction, certainly such a construction is not admissible in a taxing statute, where you can simply adhere to the words of the statute"

That part of this philosophy which infers that avoidance will succeed if it meets the letter of the law has now been discarded. Why should not the other half of the doctrine be likewise abandoned? Doubtless, it is too much to expect fair play from everyone. But it is believed that the Treasury can contribute to the elimination of questionable avoidance by adopting a more equitable and reasonable attitude toward non-avoiding taxpayern.

$220{ }_{263}$ U. S. 379 (1923). 